\title{
Porównanie samooceny potencjału zawodowego niemieckich i polskich studentów kierunków i specjalności info- i bibliologicznych
}

\author{
Marzena Świgoń \\ Zakład Archiwistyki, Bibliotekoznawstwa i Informacji Naukowej \\ Uniwersytet Warmińsko-Mazurski w Olsztynie
}

\begin{abstract}
Abstrakt
Cel/Teza: Celem badań było porównanie potencjału zawodowego (kariery, zatrudnialności) niemieckich i polskich studentów kierunków i specjalności informatologiczno-bibliologicznych.

Koncepcja/Metody badań: W obu środowiskach wykorzystano taki sam kwestionariusz, obejmujący dziewięć komponentów potencjału zawodowego, m.in. postrzeganie marki uniwersytetu, statusu studiowanej dziedziny oraz własnych umiejętności i kompetencji przydatnych na współczesnym rynku pracy.

Wyniki i wnioski: Respondenci z polskich ośrodków odznaczali się wyraźnie niższym od studentów w Niemczech poziomem samooceny niektórych komponentów potencjału zawodowego, tj. związanych ze statusem studiowanej dziedziny oraz popytem na absolwentów kierunków i specjalności info- i bibliologicznych.

Oryginalność/Wartość poznawcza: Badania są pierwszą próbą porównania potencjału kariery/ zatrudnialności niemieckich i polskich studentów studiujących nauki o książce, bibliotece i informacji.
\end{abstract}

Słowa kluczowe

Indywidualne zarządzanie wiedzą i informacją. Informacja naukowa i bibliotekoznawstwo. Potencjał kariery. Studenci. Zatrudnialność.

Otrzymany: 9 sierpnia 2016. Z Zrecenzowany: 9 listopada 2016. Zaakceptowany: 14 grudnia 2016.

\section{Wprowadzenie}

Na postrzeganie własnego potencjału zawodowego (własnej zatrudnialności) przez studentów wpływają różnorodne czynniki związane z charakterystyką indywidualną osób oraz warunkami zewnętrznymi (gospodarczymi, politycznymi i społecznymi). W świetle modelu samooceny zatrudnialności studentów (potencjału kariery, potencjału zawodowego, ang. self-perceived employability), opisanego przez autorkę m.in. na łamach Zagadnień Informacji Naukowej (Świgoń, 2014b; zob. też Świgoń, 2014a; Rothwell et al., 2008; 2009), do głównych komponentów tej samooceny należą: (1) zaangażowanie w studia i osiągane przez studentów wyniki; (2) postrzeganie marki uniwersytetu; (3) opinia o uniwersytecie odnośnie studiowanej dziedziny; (4) status, jakim w powszechnej opinii cieszy się dana dziedzina; (5) popyt na specjalistów z tej dziedziny; (6) postrzeganie aktualnej sytuacji na rynku pracy; (7) ocena swoich możliwości zatrudnienia; (8) wiara we własne umiejętności i kompetencje, w tym nabywane na danym kierunku studiów oraz (9) umiejętności związane 
$\mathrm{z}$ indywidualnym zarządzaniem wiedzą i informacją (ang. personal knowledge and information management, Świgoń, 2013). Innymi słowy, samoocena potencjału zawodowego studentów obejmuje cztery obszary, tzn. opinie o: (1) uniwersytecie, (2) studiowanym kierunku, (3) rynku pracy oraz (4) poczucie pewności siebie studentów w kontekście poszukiwania pracy. Czynniki umieszczone w narożnych komórkach modelu zobrazowanego na rysunku (Rys. 1) odzwierciedlają połączenia pomiędzy tymi czterema obszarami.

Rys. 1. Model samooceny potencjału zawodowego studentów

\begin{tabular}{|c|c|c|c|c|}
\hline \multirow{5}{*}{$\begin{array}{l}\text { Wiara } \\
\text { w siebie }\end{array}$} & \multicolumn{3}{|c|}{ Uniwersytet } & \multirow{5}{*}{ Dziedzina } \\
\hline & $\begin{array}{l}\text { 1. Zaangażowanie } \\
\text { w studia i osiągane } \\
\text { wyniki }\end{array}$ & $\begin{array}{l}\text { 2. Marka } \\
\text { uniwersytetu }\end{array}$ & $\begin{array}{l}\text { 3. Opinia } \\
\text { o uniwersytecie } \\
\text { odnośnie danej } \\
\text { dziedziny }\end{array}$ & \\
\hline & $\begin{array}{l}\text { 8. Pewność } \\
\text { siebie odnośnie } \\
\text { umiejętności } \\
\text { i kompetencji }\end{array}$ & $\begin{array}{l}\text { 9. Indywidualne } \\
\text { zarządzanie } \\
\text { wiedzą } \\
\text { i informacją }\end{array}$ & $\begin{array}{l}\text { 4. Status } \\
\text { studiowanej } \\
\text { dziedziny }\end{array}$ & \\
\hline & $\begin{array}{l}\text { 7. Aktualne } \\
\text { możliwości } \\
\text { zatrudnienia }\end{array}$ & $\begin{array}{l}\text { 6. Postrzeganie } \\
\text { sytuacji na rynku } \\
\text { pracy }\end{array}$ & $\begin{array}{l}\text { 5. Popyt na } \\
\text { specjalistów z danej } \\
\text { dziedziny }\end{array}$ & \\
\hline & & Rynek pracy & & \\
\hline
\end{tabular}

Źródło: Opracowano na podstawie (Świgoń, 2014a).

Badania nad potencjałem zawodowym prowadzone są w różnych krajach, a przykłady takich badań autorka podała we wspomnianym artykule na łamach ZIN (Świgoń, 2014b, 136). W tym miejscu warto jeszcze zwrócić uwagę na różnice pomiędzy wynikami analiz losów absolwentów przedstawionych w raportach Ogólnopolskiego Systemu Monitorowania Ekonomicznych Losów Absolwentów Szkół Wyższych ${ }^{1}$ a badaniami samooceny zatrudnialności, której dotyczy ten artykuł. Wydaje się, że badania prowadzone przez autorkę od kilku lat, nie tylko wśród studentów kierunków info- i bibliologicznych, ale także innych nauk $^{2}$, czyli badania z wykorzystaniem autorskiego modelu samooceny zatrudnialności studentów (Rys. 1), są jak na razie unikatowe. Zaprezentowane w dalszej części artykułu wyniki tej próby badań o charakterze porównawczym pomiędzy niemieckimi i polskimi studentami nauk o książce, bibliotece i informacji są kontynuacją cyklu publikacji rozpoczętego na łamach ZIN.

\footnotetext{
1 http://absolwenci.nauka.gov.pl/

2 Wyniki badań są w trakcie opracowywania lub recenzji.
} 


\section{Metodologia badań}

Badania empiryczne wśród niemieckich studentów autorka przeprowadziła w 2014 r. podczas stażu na Uniwersytecie w Hamburgu (Hochschule für Angewandte Wissenschaften Hamburg Fakultät Design, Medien und Information). Do badań o charakterze porównawczym, będących przedmiotem tego artykułu, wykorzystano część ankiet zebranych w polskich pionierskich badaniach z tego zakresu (Świgoń, 2014b), a ściślej z trzech uniwersytetów w: Krakowie, Katowicach i Wrocławiu, gdzie m.in. prowadzone jest kształcenie w zakresie informatologii i bibliologii. W takim celowym doborze polskiej próby reprezentatywnej dążono do zachowania podobieństw pomiędzy badanymi środowiskami, czyli uwzględnienia największych ośrodków akademickich, ale z wyłączeniem stolicy obu krajów. Grupę niemiecką reprezentowało 44 studentów z Uniwersytetu w Hamburgu, studiujących różne specjalności, takie jak: bibliotekoznawstwo i zarządzanie informacją, media i informacja oraz informacja, media i biblioteka. W polskiej grupie było łącznie 201 studentów kierunku informacja naukowa i bibliotekoznawstwo.

W obu grupach narodowych wykorzystano ten sam kwestionariusz ankiety zawierający łącznie 19 stwierdzeń (w odpowiedniej wersji językowej). Zadaniem respondentów było ustosunkowanie się do zaproponowanych stwierdzeń poprzez wybór jednej z odpowiedzi w skali Likerta od 1 do 5, gdzie 1 oznaczało - „zdecydowanie nie zgadzam się,, a 5 - „zdecydowanie zgadzam się".

Do opracowania uzyskanych wyników wykorzystano metody statystyczne, w tym metody statystyki opisowej i indukcyjnej. Użyto mierników statystyki opisowej, przede wszystkim odsetek obrazujących wielkość grupy wybierających daną odpowiedź, a także średnich arytmetycznych obrazujących stopień zgody z danym stwierdzeniem. Porównano rozkład odpowiedzi w obu środowiskach wykorzystując test chi-kwadrat. Przyjęto hipotezę o braku różnic w odpowiedziach pomiędzy tymi dwiema grupami, przy ustalonym poziomie istotności $\mathrm{p}<0.05$. Wyniki przedstawiono w tabelach $(1-19)$, gdzie studentów z Hamburga oznaczono symbolem DE, a polskich PL; wszystkie dane liczbowe pochodzą z materiałów źródłowych i obliczeń własnych autorki. Analizę danych przeprowadzono za pomocą oprogramowania STATISTICA 12.

Do określenia ogólnego poziomu samooceny zatrudnialności respondentów, wyrażonej średnią arytmetyczną (w odniesieniu do pojedynczych czynników oraz wszystkich łącznie), przyjęto następujące przedziały punktowe: samoocena bardzo niska: 1.00-2.21; niska: 2.22-2.65; przeciętna: 2.66-3.54; wysoka: 3.55-3.98; bardzo wysoka: 3.99-5.00.

\section{Wyniki badań}

Pierwszy z komponentów potencjału zawodowego studentów związany był z podejściem do studiów i studiowania. Respondenci z obu grup (polskiej i niemieckiej) osiągali wysokie wyniki na studiach (Tab. 1, obie średnie oceny z przedziału 3.55-3.98, czyli wysokie). Dobre oceny otrzymywali nieco częściej studenci z Hamburga (istotna statystycznie różnica pomiędzy wysokością średnich ocen). 
Tab. 1. Wyniki osiągane na studiach

\begin{tabular}{|l|c|c|c|c|}
\hline \multirow{2}{*}{\multicolumn{1}{|c}{$\begin{array}{c}\text { 1a. Osiągam wysokie wyniki } \\
\text { na studiach }\end{array}$}} & \multicolumn{2}{c|}{ DE } & \multicolumn{2}{c|}{ PL } \\
\cline { 2 - 5 } & liczba & \% & liczba & $\%$ \\
\hline 1 - zdecydowanie nie zgadzam się & 1 & 2.27 & 3 & 1.49 \\
\hline 2 - nie zgadzam się & 3 & 6.82 & 27 & 13.43 \\
\hline 3 - nie wiem & 8 & 18.18 & 63 & 31.34 \\
\hline 4 - zgadzam się & 20 & 45.45 & 82 & 40.80 \\
\hline 5 - zdecydowanie zgadzam się & 12 & 27.27 & 26 & 12.94 \\
\hline $\begin{array}{l}\text { Razem } \\
\text { Chi-kwadr. = 8.55; } \mathrm{p}=0.073\end{array}$ & 44 & 100 & 201 & 100 \\
\hline $\begin{array}{l}\text { Średnia ocena } \\
\text { F = 6.02; } \mathrm{p}=0.014\end{array}$ & 3.88 & & 3.50 & \\
\hline
\end{tabular}

Natomiast ocena studiowania jako wartości priorytetowej była w obu grupach raczej przeciętna (Tab. 2, przedział średniej oceny: 2.66-3.54). W rozkładach odpowiedzi zauważono pewne różnice. Niemieccy respondenci częściej niż polscy nie zgadzali się z zaproponowanym stwierdzeniem (chodzi o odpowiedź 2, ponad dwukrotnie częściej wybieraną w Hamburgu).

Tab. 2. Studia jako wartość priorytetowa

\begin{tabular}{|l|c|c|c|c|}
\hline \multirow{2}{*}{\multicolumn{1}{c|}{$\begin{array}{c}\text { 1b. Moje studia są dla mnie } \\
\text { wartością priorytetową }\end{array}$}} & \multicolumn{2}{c|}{ DE } & \multicolumn{2}{c|}{ PL } \\
\cline { 2 - 5 } & liczba & $\%$ & liczba & $\%$ \\
\hline 1 - zdecydowanie nie zgadzam się & 0 & 0 & 13 & 6.47 \\
\hline 2 - nie zgadzam się & 14 & 31.82 & 27 & 13.43 \\
\hline 3 - nie wiem & 7 & 15.91 & 39 & 19.40 \\
\hline 4- zgadzam się & 16 & 36.36 & 94 & 46.77 \\
\hline 5 - zdecydowanie zgadzam się & 7 & 15.91 & 28 & 13.93 \\
\hline $\begin{array}{l}\text { Razem } \\
\text { Chi-kwadr. = 11.34; } \mathrm{p}=0.022\end{array}$ & 44 & 100 & 201 & 100 \\
\hline $\begin{array}{l}\text { Średnia ocena } \\
\text { F = 0.42; } \mathrm{p}=0.513\end{array}$ & 3.36 & & 3.48 & \\
\hline
\end{tabular}

Drugi z komponentów potencjału zawodowego dotyczył postrzegania marki danej uczelni. W odniesieniu do pierwszego z dwóch reprezentujących ten komponent stwierdzeń, nie zaobserwowano żadnych różnic w obu porównywanych grupach studentów. Innymi słowy, w opinii badanych pracodawcy są zainteresowani absolwentami danych uczelni w stopniu raczej przeciętnym. Aczkolwiek zwraca uwagę duży odsetek studentów w ogóle niezorientowanych w tej kwestii. Ponad 63\% studentów niemieckich i ponad 54\% polskich nie wiedziało jak pracodawcy oceniają kształcenie na uwzględnionych uczelniach. 
Tab. 3. Zatrudnianie absolwentów danej uczelni

\begin{tabular}{|l|c|c|c|c|}
\hline \multirow{2}{*}{$\begin{array}{c}\text { 2a. Pracodawcy chętnie zatrudniają } \\
\text { absolwentów mojego uniwersytetu }\end{array}$} & \multicolumn{2}{|c|}{ DE } & \multicolumn{2}{c|}{ PL } \\
\cline { 2 - 5 } & liczba & $\%$ & liczba & $\%$ \\
\hline 1 - zdecydowanie nie zgadzam się & 1 & 2.27 & 9 & 4.48 \\
\hline 2 - nie zgadzam się & 6 & 13.64 & 20 & 9.95 \\
\hline 3 - nie wiem & 28 & 63.64 & 109 & 54.23 \\
\hline 4- zgadzam się & 7 & 15.91 & 45 & 22.39 \\
\hline 5 - zdecydowanie zgadzam się & 2 & 4.55 & 18 & 8.96 \\
\hline $\begin{array}{l}\text { Razem } \\
\text { Chi-kwadr. = 3.03; } \mathrm{p}=0.551\end{array}$ & 44 & 100 & 201 & 100 \\
\hline $\begin{array}{l}\text { Średnia ocena } \\
\text { F = 0.98; } \mathrm{p}=0.321\end{array}$ & 3.06 & & 3.21 & \\
\hline
\end{tabular}

Ponad jedna trzecia respondentów w obu grupach nie była zorientowana czy marka ich uczelni jest ich faktycznym atutem na rynku pracy (drugie ze wspomnianych stwierdzeń, Tab. 4). Zauważono tu jednak istotne różnice statystycznie, zarówno w odniesieniu do średnich ocen z odpowiedzi, jak i szczegółowych ich rozkładów. Zdecydowanie lepszą ocenę wystawili swojej uczelni w omawianym zakresie studenci w Polsce niż Niemczech (według ustalonych przedziałów, średnie były odpowiednio: wysoka i przeciętna). Wyraźnie częściej wybierali oceny zgody (4 i 5), było to łącznie ponad 56\% respondentów w Polsce w porównaniu do $34 \%$ w Hamburgu, gdzie dodatkowo nikt nie zaznaczył najwyższej oceny. Więcej też studentów niemieckich niż polskich (27\% i 9\%) nie zgodziło się ze stwierdzeniem, że marka ich uczelni jest atutem na rynku pracy.

Tab. 4. Marka uczelni

\begin{tabular}{|l|c|c|c|c|}
\hline \multirow{2}{*}{$\begin{array}{c}\text { 2b. Marka mojego uniwersytetu jest } \\
\text { moim atutem na rynku pracy }\end{array}$} & \multicolumn{2}{|c|}{ DE } & \multicolumn{2}{c|}{ PL } \\
\cline { 2 - 5 } & liczba & $\%$ & liczba & $\%$ \\
\hline 1 - zdecydowanie nie zgadzam się & 3 & 6.82 & 8 & 3.98 \\
\hline 2 - nie zgadzam się & 9 & 20.45 & 12 & 5.97 \\
\hline 3 - nie wiem & 17 & 38.64 & 68 & 33.83 \\
\hline 4- zgadzam się & 15 & 34.09 & 65 & 32.34 \\
\hline 5 - zdecydowanie zgadzam się & 0 & 0 & 48 & 23.88 \\
\hline $\begin{array}{l}\text { Razem } \\
\text { Chi-kwadr. }=20.26 ; \mathrm{p}<0.001\end{array}$ & 44 & 100 & 201 & 100 \\
\hline $\begin{array}{l}\text { Średnia ocena } \\
\text { F }=15.42 ; \mathrm{p}<0.001\end{array}$ & 3.00 & & 3.66 & \\
\hline
\end{tabular}

O ile powyżej mieliśmy do czynienia z ogólną opinią o uczelni, o tyle w kolejnym komponencie potencjału zawodowego uwypuklony został aspekt powiązania z konkretną dyscypliną. Uogólniając, można zauważyć, że specjalności informatologiczno-bibliologiczne w Polsce i w Niemczech są niezbyt doceniane (Tab. 5 i 6, wszystkie średnie z przedziału 
ocen przeciętnych, brak istotnych różnic w podgrupach narodowych). W odniesieniu do pierwszego z dwóch stwierdzeń (Tab. 5) zwraca uwagę bardzo duża grupa osób niezorientowanych jak pracodawcy związani z informacją, książką i bibliotekami oraz inni z obszaru zawodów informacyjnych postrzegają kształcenie w tej dziedzinie na danej uczelni (54\% w Niemczech i 62\% w Polsce). Jednakże, co czwarty z respondentów w Hamburgu i co piąty z naszych uczelni był przekonany, że pracodawcy chętnie zatrudniają absolwentów takich kierunków i specjalności.

Tab. 5. Uczelnia w oczach pracodawców z danej dziedziny

\begin{tabular}{|l|c|c|c|c|}
\hline \multirow{2}{*}{$\begin{array}{c}\text { 3a. Pracodawcy związani z dziedziną, } \\
\text { którą studiuję, szczególnie chętnie } \\
\text { zatrudniają absolwentów właśnie } \\
\text { mojego uniwersytetu }\end{array}$} & liczba & $\%$ & liczba & $\%$ \\
\cline { 2 - 5 } & 1 & 2.27 & 10 & 4.98 \\
\hline 1 - zdecydowanie nie zgadzam się & 8 & 18.18 & 16 & 7.96 \\
\hline 2- nie zgadzam się & 24 & 54.55 & 126 & 62.69 \\
\hline 3- nie wiem & 9 & 20.45 & 39 & 19.40 \\
\hline 4- zgadzam się & 2 & 4.55 & 10 & 4.98 \\
\hline 5 - zdecydowanie zgadzam się & 44 & 100 & 201 & 100 \\
\hline $\begin{array}{l}\text { Razem } \\
\text { Chi-kwadr. = 4.86; } \mathrm{p}=0.301\end{array}$ & 3.06 & & 3.11 & \\
\hline $\begin{array}{l}\text { Średnia ocena } \\
\text { F = 0.11; } \mathrm{p}=0.733\end{array}$ & & & \\
\hline
\end{tabular}

Nieco lepiej była postrzegana reputacja uwzględnionych uczelni w zakresie kształcenia na danych kierunkach i specjalnościach (obie średnie były wyższe niż poprzednio omówione, choć mieściły się także w przedziale ocen przeciętnych, Tab. 6). Znowu zwracają uwagę duże grupy niezorientowanych studentów (po około 45\%). Można też zauważyć, że polscy studenci częściej wybierali oceny zgody z zaproponowanym stwierdzeniem i rzadziej oceny niezgody, niż studenci z Hamburga. Uniwersytety we Wrocławiu, Katowicach i Krakowie należą bowiem do wiodących w tej dziedzinie w naszym kraju.

Czwartym komponentem potencjału zawodowego była opinia o studiowanej dziedzinie. Ilustrowały ją dwa stwierdzenia: o popularności kierunku wśród kandydatów oraz o skojarzeniach z wysokim statusem społecznym (Tab. 7 i 8). Od razu trzeba podkreślić, że zaobserwowano tu bardzo znaczące statystycznie różnice w odpowiedziach studentów z Polski i Niemiec. W świetle odpowiedzi respondentów, kierunki i specjalności bibliologiczno-informatologiczne cieszą się dużo większą popularnością wśród kandydatów w Niemczech niż w naszym kraju. Aż połowa respondentów z Hamburga zgodziła się ze stwierdzeniem, że liczba kandydatów na jedno miejsce jest tam duża, podczas gdy wśród polskich studentów było to tylko 8\% (Tab. 7). I odwrotnie, aż 70\% naszych respondentów nie zgodziło się z omawianym stwierdzeniem, a u sąsiadów tylko 18\%. Istotne statystycznie różnice zaobserwowano nie tylko w rozkładach odpowiedzi, ale także w wysokości średniej oceny zgody. W Polsce była ona bardzo niska (najniższy z przedziałów), a w Niemczech przeciętna. 
Tab. 6. Reputacja uczelni w danej dziedzinie

\begin{tabular}{|l|c|c|c|c|}
\hline \multirow{2}{*}{$\begin{array}{c}\text { 3b. Mój uniwersytet cieszy się } \\
\text { wspaniałą reputacją w dziedzinie, } \\
\text { którą studiuję }\end{array}$} & \multicolumn{2}{|c|}{ DE } & \multicolumn{2}{c|}{ PL } \\
\cline { 2 - 5 } & liczba & $\%$ & liczba & $\%$ \\
\hline 1 - zdecydowanie nie zgadzam się & 1 & 2.27 & 4 & 1.99 \\
\hline 2- nie zgadzam się & 7 & 15.91 & 12 & 5.97 \\
\hline 3- nie wiem & 20 & 45.45 & 93 & 46.27 \\
\hline $4-$ zgadzam się & 13 & 29.55 & 69 & 34.33 \\
\hline 5 - zdecydowanie zgadzam się & 3 & 6.82 & 23 & 11.44 \\
\hline $\begin{array}{l}\text { Razem } \\
\text { Chi-kwadr. = 5.59; p = 0.231 }\end{array}$ & 44 & 100 & 201 & 100 \\
\hline $\begin{array}{l}\text { Średnia ocena } \\
\text { F = 2.96; } \mathrm{p}=0.086\end{array}$ & 3.22 & & 3.47 & \\
\hline
\end{tabular}

Tab. 7. Popularność kierunku studiów

\begin{tabular}{|l|c|c|c|c|}
\hline \multirow{2}{*}{$\begin{array}{c}\text { 4a. Liczba kandydatów na jedno } \\
\text { miejsce na moim kierunku jest duża }\end{array}$} & \multicolumn{2}{|c|}{ DE } & \multicolumn{2}{c|}{ PL } \\
\cline { 2 - 5 } & liczba & $\%$ & liczba & $\%$ \\
\hline 1 - zdecydowanie nie zgadzam się & 3 & 6.82 & 59 & 29.35 \\
\hline 2 - nie zgadzam się & 5 & 11.36 & 81 & 40.30 \\
\hline 3 - nie wiem & 14 & 31.82 & 44 & 21.89 \\
\hline 4 - zgadzam się & 11 & 25.00 & 12 & 5.97 \\
\hline 5 - zdecydowanie zgadzam się & 11 & 25.00 & 5 & 2.49 \\
\hline $\begin{array}{l}\text { Razem } \\
\text { Chi-kwadr. }=59.29 ; \mathrm{p}<0.001\end{array}$ & 44 & 100 & 201 & 100 \\
\hline $\begin{array}{l}\text { Średnia ocena } \\
\text { F = 65.78; } \mathrm{p}<0.001\end{array}$ & 3.50 & & 2.11 & \\
\hline
\end{tabular}

Kierunki i specjalności bibliologiczno-informatologiczne nie wiążą się z wysokim statusem społecznym ani w Polsce, ani w Niemczech. Bardzo niską średnią ocenę zgody z ilustrującym tę kwestię stwierdzeniem uzyskano z ocen studentów polskich oraz niską z odpowiedzi w Niemczech (Tab. 8). Opinię o wysokim statusie społecznym zawodów informacyjnych wyraziło jedynie 13\% respondentów w Hamburgu i 8\% w Polsce.

Kolejny element modelu potencjału zawodowego studentów związany był z popytem na absolwentów z konkretnym wykształceniem, już bez związku z daną uczelnią i jej marką (Tab. 9 i 10). Pierwsze z ilustrujących go stwierdzeń dotyczyło przekonania o popycie na pracowników wykonujących zawody informacyjne, a drugie powiązania takich zawodów z ogólnie pożądanym modelem kariery. W obu przypadkach zaobserwowano istotne statystycznie różnice w odpowiedziach polskich i niemieckich respondentów. Średnia ocena zgody ze stwierdzeniem o dużym popycie na pracowników informacji (Tab. 9) była w Hamburgu znacząco wyższa (w przedziale przeciętnych ocen) niż w Polsce (ocena niska). Z tym stwierdzeniem zdecydowanie nie zgodziło się jedynie $4 \%$ niemieckich studentów w porównaniu do $23 \%$ polskich. 
Tab. 8. Kierunek studiów a status społeczny

\begin{tabular}{|l|c|c|c|c|}
\hline \multirow{2}{*}{$\begin{array}{c}\text { 4b. Wybrany przeze mnie kierunek } \\
\text { wiąże się z wysokim statusem } \\
\text { spolecznym }\end{array}$} & \multicolumn{2}{|c|}{ DE } & \multicolumn{2}{c|}{ PL } \\
\cline { 2 - 5 } & liczba & $\%$ & liczba & $\%$ \\
\hline 1 - zdecydowanie nie zgadzam się & 5 & 11.36 & 48 & 23.88 \\
\hline 2 - nie zgadzam się & 12 & 27.27 & 87 & 43.28 \\
\hline 3 - nie wiem & 21 & 47.73 & 49 & 24.38 \\
\hline 4 - zgadzam się & 6 & 13.64 & 15 & 7.46 \\
\hline 5 - zdecydowanie zgadzam się & 0 & 0 & 2 & 1.00 \\
\hline $\begin{array}{l}\text { Razem } \\
\text { Chi-kwadr. = 13.83; } \mathrm{p}=0.007\end{array}$ & 44 & 100 & 201 & 100 \\
\hline $\begin{array}{l}\text { Średnia ocena } \\
\text { F = 8.95; } \mathrm{p}=0.003\end{array}$ & 2.63 & & 2.18 & \\
\hline
\end{tabular}

Tab. 9. Popyt na absolwentów danego kierunku

\begin{tabular}{|l|c|c|c|c|}
\hline \multirow{2}{*}{$\begin{array}{c}\text { 5a. Osoby wykonujące zawód, } \\
\text { do którego się przygotowuję, są } \\
\text { bardzo poszukiwanie na rynku pracy }\end{array}$} & liczba & \% & liczba & \% \\
\cline { 2 - 5 } & 2 & 4.55 & 48 & 23.88 \\
\hline 1 - zdecydowanie nie zgadzam się & 15 & 34.09 & 69 & 34.33 \\
\hline 2 - nie zgadzam się & 21 & 47.73 & 69 & 34.33 \\
\hline 3 - nie wiem & 5 & 11.36 & 13 & 6.46 \\
\hline 4 - zgadzam się & 1 & 2.27 & 2 & 1.00 \\
\hline 5 - zdecydowanie zgadzam się & 44 & 100 & 201 & 100 \\
\hline $\begin{array}{l}\text { Razem } \\
\text { Chi-kwadr. = 10.03; } \mathrm{p}=0.039\end{array}$ & 2.72 & & 2.26 & \\
\hline $\begin{array}{l}\text { Średnia ocena } \\
\text { F = 9.34; } \mathrm{p}=0.002\end{array}$ & & & \\
\hline
\end{tabular}

Podobne różnice zaobserwowano w odniesieniu do drugiego stwierdzenia, czyli postrzegania wagi dyplomu ukończenia kierunków i specjalności informacyjnych. Średnia ocena zgody w Niemczech była niska, a w Polsce bardzo niska (Tab. 10), przy czym jedynie 2\% studentów w Hamburgu i 26\% w Polsce zdecydowanie nie poparło stwierdzenia o powiązaniu dyplomu ukończenia takich studiów z ogólnie pożądaną karierą.

Następny komponent samooceny zatrudnialności studentów związany był z opinią czy istnieje obecnie popyt na pracowników z wyższym wykształceniem i czy jest dużo ofert pracy w danym regionie (Tab. 11 i 12). Odnośnie do pierwszej kwestii zauważono różnicę w częstotliwości zaznaczania odpowiedzi „nie wiem”, tzn. dwa razy więcej respondentów w Niemczech niż w Polsce nie wiedziało czy istnieje duże zapotrzebowanie na osoby z wyższym wykształceniem (Tab. 11). Ogółem, z odpowiedzi w obu porównywanych grupach respondentów wynika, że nie ma dużego popytu na wysoko wykwalifikowanych absolwentów, z czym zgadzał się co trzeci respondent. 
Tab. 10. Dyplom danego kierunku a kariera

\begin{tabular}{|l|c|c|c|c|}
\hline \multirow{2}{*}{$\begin{array}{c}\text { 5b. Dyplom mojego kierunku studiów } \\
\text { jest postrzegany jako droga do takiej } \\
\text { kariery, która jest ogólnie postrzega- } \\
\text { na jako bardzo pożądana }\end{array}$} & liczba & $\%$ & liczba & $\%$ \\
\cline { 2 - 5 } & 1 & 2.27 & 53 & 26.37 \\
\hline - zdecydowanie nie zgadzam się & 19 & 43.18 & 80 & 39.80 \\
\hline 2 - nie zgadzam się & 19 & 43.18 & 53 & 26.37 \\
\hline 4- nie wiem & 5 & 11.37 & 13 & 6.46 \\
\hline 5 - zdecydzam się & 0 & 0 & 2 & 1.00 \\
\hline $\begin{array}{l}\text { Razem } \\
\text { Chi-kwadr. = 14.69; } \mathrm{p}=0.005\end{array}$ & 44 & 100 & 201 & 100 \\
\hline $\begin{array}{l}\text { Średnia ocena } \\
\text { F }=10.34 ; \mathrm{p}=0.001\end{array}$ & 2.63 & & 2.15 & \\
\hline
\end{tabular}

Tab. 11. Popyt na osoby z wyższym wykształceniem

\begin{tabular}{|l|c|c|c|c|}
\hline \multirow{2}{*}{$\begin{array}{c}\text { 6a. Dzisiaj jest duże zapotrzebowanie } \\
\text { na ludzi po studiach }\end{array}$} & \multicolumn{2}{|c|}{ DE } & \multicolumn{2}{c|}{ PL } \\
\cline { 2 - 5 } & liczba & $\%$ & liczba & $\%$ \\
\hline 1 - zdecydowanie nie zgadzam się & 2 & 4.55 & 30 & 14.93 \\
\hline 2 - nie zgadzam się & 10 & 22.72 & 47 & 23.37 \\
\hline 3 - nie wiem & 15 & 34.09 & 33 & 16.42 \\
\hline 4 - zgadzam się & 15 & 34.09 & 62 & 30.85 \\
\hline 5 - zdecydowanie zgadzam się & 2 & 4.55 & 29 & 14.43 \\
\hline $\begin{array}{l}\text { Razem } \\
\text { Chi-kwadr. = 11.64; } \mathrm{p}=0.020\end{array}$ & 44 & 100 & 201 & 100 \\
\hline $\begin{array}{l}\text { Średnia ocena } \\
\text { F = 0.05; } \mathrm{p}=0.815\end{array}$ & 3.11 & & 3.06 & \\
\hline
\end{tabular}

Odnośnie do drugiego ze wspomnianych stwierdzeń, czyli liczby ofert pracy, zwraca uwagę niska średnia z uzyskanych odpowiedzi w obu środowiskach. Chodziło o region lub regiony, w których ankietowani chcieliby pracować (Tab. 12). W Hamburgu 27\% uważało, że ofert pracy jest dużo, a w trzech polskich miastach zdanie to podzielało jedynie $11 \%$ respondentów. Jednakże ponad połowa obu grup studentów zaznaczyła brak zgody (odpowiedzi 4 i 5 łącznie).

Kolejny komponent potencjału zawodowego studentów dotyczył także ofert pracy, ale już ściśle związanych ze studiowaną dziedziną oraz umiejętności nabywanych na konkretnych studiach (Tab. 13 i 14). Z opinii respondentów wynikało wyraźnie, że znalezienie pracy w zawodach informacyjnych jest dużo łatwiejsze w Hamburgu niż w badanych trzech miastach w Polsce. Połowa niemieckich respondentów zgodziła się z przedmiotowym stwierdzeniem (Tab. 13), w Polsce było to jedynie 9\%. I odwrotnie, negatywnych odpowiedzi było trzy razy więcej w naszych miastach w porównaniu do 
studiujących w Hamburgu. Na niezbyt wysokie średnie ze wszystkich udzielonych odpowiedzi wpłynęła z pewnością jedna trzecia osób w ogóle niezorientowanych w omawianej kwestii.

Tab. 12. Liczba ofert pracy w danym regionie

\begin{tabular}{|l|c|c|c|c|}
\hline \multirow{2}{*}{$\begin{array}{c}\text { 6b. Jest dużo ofert pracy w regionie, } \\
\text { w którym chciaf(a)bym pracować }\end{array}$} & \multicolumn{2}{|c|}{ DE } & \multicolumn{2}{c|}{ PL } \\
\cline { 2 - 5 } 1 liczba & \% & liczba & $\%$ \\
\hline 2 - ndecydowanie ngad zgadzam się & 6 & 13.64 & 38 & 18.91 \\
\hline 3 - nie wiem & 17 & 38.64 & 72 & 35.82 \\
\hline 4- zgadzam się & 9 & 20.45 & 67 & 33.33 \\
\hline 5 - zdecydowanie zgadzam się & 9 & 20.45 & 20 & 9.95 \\
\hline $\begin{array}{l}\text { Razem } \\
\text { Chi-kwadr. }=8.87 ; \mathrm{p}=0.064\end{array}$ & 3 & 6.82 & 4 & 1.99 \\
\hline $\begin{array}{l}\text { Średnia ocena } \\
\text { F }=2.77 ; \mathrm{p}=0.097\end{array}$ & 2.68 & 100 & 201 & 100 \\
\hline
\end{tabular}

Tab. 13. Oferty pracy w danej dziedzinie

\begin{tabular}{|l|c|c|c|c|}
\hline \multicolumn{1}{|c|}{$\begin{array}{c}\text { 7a. Dosyć łatwo mogę znaleźć } \\
\text { oferty pracy, w wybranej przeze } \\
\text { mnie dziedzinie }\end{array}$} & liczba & $\%$ & liczba & $\%$ \\
\cline { 2 - 5 } & 2 & 4.55 & 42 & 20.90 \\
\hline 1 - zdecydowanie nie zgadzam się & 6 & 13.64 & 81 & 40.30 \\
\hline 2 - nie zgadzam się & 14 & 31.81 & 58 & 28.85 \\
\hline 3 - nie wiem & 18 & 40.91 & 16 & 7.96 \\
\hline 4 - zgadzam się & 4 & 9.09 & 4 & 1.99 \\
\hline 5 - zdecydowanie zgadzam się & 44 & 100 & 201 & 100 \\
\hline $\begin{array}{l}\text { Razem } \\
\text { Chi-kwadr. = 46.52; } p<0.001\end{array}$ & 3.36 & & 2.29 & \\
\hline $\begin{array}{l}\text { Średnia ocena } \\
\text { F = 44.37; }<<0.001\end{array}$ & & & \\
\hline
\end{tabular}

Studiujący w Hamburgu byli bardziej od naszych studentów przekonani o tym, że nabywane przez nich umiejętności są tym, czego faktycznie szukają pracodawcy. Odpowiedzi potwierdzające wybrało odpowiednio $47 \%$ i $32 \%$ respondentów (Tab. 14). Ponownie zastanawiać może jednak spora grupa niezorientowanych w tym temacie respondentów w obu środowiskach (36-45\%). Obie średnie oceny tego stwierdzenia wskazywały jedynie na przeciętne oczekiwania studentów co do zainteresowania pracodawców ich umiejętnościami zawodowymi.

Ósmy komponent zatrudnialności dotyczył powodzenia na rozmowach kwalifikacyjnych oraz prognoz dotyczących znalezienia pracy w dalszej przyszłości (Tab. 15 i 16). W ocenie obu stwierdzeń nie zaobserwowano istotnych statystycznie różnic w podgrupach narodowych. Sukcesu na rozmowach kwalifikacyjnych (Tab. 15) spodziewali w takim samym 
stopniu - tylko przeciętnym - studenci w Hamburgu, jak i w polskich miastach. Warto zwrócić uwagę na dużą grupę ankietowanych niepewnych co do swojego powodzenia w procesie rekrutacji zawodowej. Stanowili oni 36\% w Hamburgu i 43\% w polskich miastach. Natomiast pewnych swojego sukcesu było 43\% studentów w Niemczech i znacznie mniej, bo $26 \%$ w Polsce.

Tab. 14. Indywidualne umiejętności a potrzeby pracodawców

\begin{tabular}{|l|c|c|c|c|}
\hline \multirow{2}{*}{$\begin{array}{c}\text { 7b. Umiejętności i zdolności, } \\
\text { które posiadam, są tym, } \\
\text { czego szukają pracodawcy }\end{array}$} & \multicolumn{2}{|c|}{ DE } & \multicolumn{2}{c|}{ PL } \\
\cline { 2 - 5 } & liczba & $\%$ & liczba & $\%$ \\
\hline 1 - zdecydowanie nie zgadzam się & 0 & 0 & 11 & 5.47 \\
\hline 2- nie zgadzam się & 7 & 15.92 & 34 & 16.92 \\
\hline 3- nie wiem & 16 & 36.36 & 91 & 45.27 \\
\hline 4 - zgadzam się & 16 & 36.36 & 57 & 28.36 \\
\hline 5 - zdecydowanie zgadzam się & 5 & 11.36 & 8 & 3.98 \\
\hline $\begin{array}{l}\text { Razem } \\
\text { Chi-kwadr. }=7.57 ; \mathrm{p}=0.108\end{array}$ & 44 & 100 & 201 & 100 \\
\hline $\begin{array}{l}\text { Średnia ocena } \\
\text { F = 5.27; } \mathrm{p}=0.022\end{array}$ & 3.43 & & 3.08 & \\
\hline
\end{tabular}

Tab. 15. Pewność siebie w procesie rekrutacji zawodowej

\begin{tabular}{|l|c|c|c|c|}
\hline \multirow{2}{*}{$\begin{array}{c}\text { 8a. Jestem pewny swojego sukcesu na } \\
\text { rozmowach kwalifikacyjnych } \\
\text { i różnych etapach rekrutacji }\end{array}$} & \multicolumn{2}{|c|}{ DE } & \multicolumn{2}{c|}{ PL } \\
\cline { 2 - 5 } & liczba & $\%$ & liczba & $\%$ \\
\hline 1 - zdecydowanie nie zgadzam się & 3 & 6.82 & 22 & 10.95 \\
\hline 2 - nie zgadzam się & 6 & 13.64 & 38 & 18.91 \\
\hline 3 - nie wiem & 16 & 36.36 & 87 & 43.28 \\
\hline 4- zgadzam się & 16 & 36.36 & 40 & 19.90 \\
\hline 5 - zdecydowanie zgadzam się & 3 & 6.82 & 14 & 6.96 \\
\hline $\begin{array}{l}\text { Razem } \\
\text { Chi-kwadr. }=5.85 ; \mathrm{p}=0.210\end{array}$ & 44 & 100 & 201 & 100 \\
\hline $\begin{array}{l}\text { Średnia ocena } \\
\text { F = 2.92; } \mathrm{p}=0.088\end{array}$ & 3.22 & & 2.93 & \\
\hline
\end{tabular}

Drugie ze stwierdzeń w tym komponencie było również podobnie ocenione przez respondentów z dwóch środowisk, czyli różnice w rozkładach odpowiedzi oraz w średnich nie były istotne statystycznie (Tab. 16). Przeważająca część studentów w Niemczech (52\%) i w Polsce (42\%), była przekonana, że w przyszłości nie napotka trudności w poszukiwaniu pracy jeżeli tylko zadba o samodoskonalenie zawodowe. Wprawdzie co trzeci student nie był tego pewien, ale pesymistów w tym zakresie było jeszcze mniej (18\% i $21 \%$ ). 
Tab. 16. Prognozy zawodowe

\begin{tabular}{|l|c|c|c|c|}
\hline \multirow{2}{*}{$\begin{array}{c}\text { 8b. Uważam, że mógłbym dostać } \\
\text { każdą pracę, tak długo, jak moje } \\
\text { umiejętności i doświadczenie } \\
\text { będą odpowiednie }\end{array}$} & liczba & \% & liczba & $\%$ \\
\cline { 2 - 5 } & 1 & 2.27 & 11 & 5.47 \\
\hline 1 - zdecydowanie nie zgadzam się & 7 & 15.91 & 31 & 15.42 \\
\hline 2- nie zgadzam się & 13 & 29.55 & 74 & 36.82 \\
\hline 3- nie wiem & 19 & 43.18 & 68 & 33.83 \\
\hline 4- zgadzam się & 4 & 9.09 & 17 & 8.46 \\
\hline 5 - zdecydowanie zgadzam się & 44 & 100 & 201 & 100 \\
\hline $\begin{array}{l}\text { Razem } \\
\text { Chi-kwadr. = 2.20; } \mathrm{p}=0.698\end{array}$ & 3.40 & & 3.24 & \\
\hline $\begin{array}{l}\text { Średnia ocena } \\
\text { F = 1.00; } \mathrm{p}=0.316\end{array}$ & & & \\
\hline
\end{tabular}

Komponent dotyczący związków indywidualnego zarządzania informacją i wiedzą z poczuciem zatrudnialności (Tab. 17 i 18) został oceniony w obu środowiskach najwyżej, tzn. uzyskał średnie z przedziału wysokich (żaden nie uzyskał ocen bardzo wysokich). Badani studenci byli przekonani w zdecydowanej większości (74\% i 68\%), że umiejętności poszukiwania, oceniania, prezentowania informacji i pomysłów znacząco ułatwiają poszukiwanie pracy (Tab. 17).

Tab. 17. Umiejętności zarządzania indywidualną wiedzą i informacją a poszukiwanie pracy

\begin{tabular}{|l|c|c|c|c|}
\hline \multirow{2}{*}{$\begin{array}{c}\text { 9a. Uważam, że odpowiednie } \\
\text { zarządzanie posiadaną wiedzą } \\
\text { przez studentów, tj. poszukiwanie, } \\
\text { ocenianie, prezentowanie (informacji } \\
\text { i pomysłów), itp. znacząco ułatwia } \\
\text { poszukiwanie pracy i zdobywanie } \\
\text { zatrudnienia }\end{array}$} & liczba & \% & liczba & $\%$ \\
\hline $\begin{array}{l}\text { 1 - zdecydowanie nie zgadzam się } \\
\text { 2- nie zgadzam się }\end{array}$ & 1 & 2.27 & 4 & 1.99 \\
\hline 3- nie wiem & 2 & 4.55 & 18 & 8.96 \\
\hline 4- zgadzam się & 8 & 18.18 & 41 & 20.40 \\
\hline 5 - zdecydowanie zgadzam się & 26 & 59.09 & 99 & 49.25 \\
\hline $\begin{array}{l}\text { Razem } \\
\text { Chi-kwadr. = 8.55; } \mathrm{p}=0.073\end{array}$ & 44 & 15.91 & 39 & 19.40 \\
\hline $\begin{array}{l}\text { Średnia ocena } \\
\text { F = 1.88; } \mathrm{p}=0.757\end{array}$ & 3.81 & & 201 & 100 \\
\hline
\end{tabular}

Podobnie liczne grupy respondentów w obu środowiskach (81\% i 65\%) wysoko oceniły przygotowanie, jakie otrzymują na swoich studiach do indywidualnego zarządzania 
informacją i wiedzą (Tab. 18). Warto jednak zwrócić uwagę na częstotliwość zaznaczania w tej kwestii odpowiedzi nie wiem, którą w Niemczech wybrało tylko 6\%, a w Polsce 25\%. Taki wynik w naszych miastach może dziwić, zważywszy, że mowa jest o umiejętnościach immanentnie związanych $\mathrm{z}$ informatologią.

Tab. 18. Przygotowanie do zarządzania indywidualną informacją i wiedzą na studiach

\begin{tabular}{|c|c|c|c|c|}
\hline \multirow{2}{*}{$\begin{array}{l}\text { 9b. Na moich studiach jestem dobrze } \\
\text { przygotowywany do zarządzania } \\
\text { (poszukiwania, oceniania, prezento- } \\
\text { wania itp.) informacją i wiedzą }\end{array}$} & \multicolumn{2}{|c|}{ DE } & \multicolumn{2}{|c|}{ PL } \\
\hline & liczba & $\%$ & liczba & $\%$ \\
\hline 1 - zdecydowanie nie zgadzam się & 2 & 4.55 & 8 & 3.98 \\
\hline 2 - nie zgadzam się & 3 & 6.82 & 9 & 4.48 \\
\hline 3 - nie wiem & 3 & 6.82 & 52 & 25.86 \\
\hline 4 - zgadzam się & 27 & 61.36 & 106 & 52.74 \\
\hline 5 - zdecydowanie zgadzam się & 9 & 20.45 & 26 & 12.94 \\
\hline $\begin{array}{l}\text { Razem } \\
\text { Chi-kwadr. }=8.19 ; \mathrm{p}=0.084\end{array}$ & 44 & 100 & 201 & 100 \\
\hline $\begin{array}{l}\text { Średnia ocena } \\
F=1.75 ; p=0.186\end{array}$ & 3.86 & & 3.66 & \\
\hline
\end{tabular}

Ostatnie z pytań w kwestionariuszu dotyczyło szans studentów w poszukiwaniu pracy za granicą (Tab. 19) i było związane z omówionym wcześniej komponentem dotyczącym perspektyw zatrudnienia (oznaczonym numerem ósmym, Tab. 15 i 16). Dwa razy więcej respondentów w Hamburgu niż w polskich miastach (38\% i 19\%) było pewnych swojego powodzenia w szukaniu pracy za granicą, przy sporej grupie wybierających odpowiedź nie wiem (odpowiednio: 34\% i 45\%). Ogółem średnia ocena własnych szans w obu środowiskach była jednak tylko przeciętna.

Tab. 19. Szanse na zagranicznych rynkach pracy

\begin{tabular}{|c|c|c|c|c|}
\hline \multirow{2}{*}{$\begin{array}{l}\text { 10. Uważam, że mam duże szanse } \\
\text { znalezienia zatrudnienia - odpo- } \\
\text { wiadającego moim kwalifikacjom } \\
\text { i oczekiwaniom - za granicą }\end{array}$} & \multicolumn{2}{|c|}{$\mathrm{DE}$} & \multicolumn{2}{|c|}{ PL } \\
\hline & liczba & $\%$ & liczba & $\%$ \\
\hline 1 - zdecydowanie nie zgadzam się & 2 & 4.55 & 25 & 12.44 \\
\hline 2 - nie zgadzam się & 10 & 22.72 & 43 & 21.39 \\
\hline 3 - nie wiem & 15 & 34.09 & 91 & 45.27 \\
\hline 4 - zgadzam się & 15 & 34.09 & 29 & 14.43 \\
\hline 5 - zdecydowanie zgadzam się & 2 & 4.55 & 13 & 6.47 \\
\hline $\begin{array}{l}\text { Razem } \\
\text { Chi-kwadr. = 11.10; } \mathrm{p}=0.025\end{array}$ & 44 & 100 & 201 & 100 \\
\hline $\begin{array}{l}\text { Średnia ocena } \\
\mathrm{F}=3.12 ; \mathrm{p}=0.078\end{array}$ & 3.11 & & 2.81 & \\
\hline
\end{tabular}




\section{Podsumowanie}

Ogólne samooceny potencjału zawodowego studentów nauk o książce, bibliotece i informacji w dwóch badanych grupach respondentów - w Hamburgu oraz w trzech polskich miastach (Krakowie, Wrocławiu i Katowicach) - były przeciętne, wyniosły odpowiednio 3.21 i 2.96 (w skali 1-5). Wysokie średnie samooceny dotyczyły w obu środowiskach jedynie dwóch kwestii, czyli dwóch z dziewięciu komponentów modelu zatrudnialności zobrazowanego na Rys. 1 . Były to wyniki na studiach i przygotowanie w zakresie indywidualnego zarządzania wiedzą i informacją.

Pozostałe samooceny innych składowych komponentów były na ogół przeciętne z kilkoma bardzo charakterystycznymi wyjątkami. Pierwszym z nich była ocena marki uczelni, którą polscy studenci ocenili wysoko, a w Hamburgu - przeciętnie. Natomiast w innych wyjątkach, oceny respondentów w obu grupach narodowych były odwrotne do wspomnianych. Otóż polscy studenci wybierali niskie oceny, wyraźnie niższe niż niemieccy studenci, właściwie przy wszystkich stwierdzeniach dotyczących kierunku studiów, jego popularności wśród kandydatów, statusu społecznego absolwentów i kariery z nim związanej, popytu na absolwentów tego kierunku oraz liczby ofert pracy w zawodach informacyjnych. Innymi słowy wydaje się, że zawody te są jeszcze niezbyt doceniane w naszym kraju, a przynajmniej - w świetle uzyskanych wyników - mniej niż na rynku niemieckim. To była najbardziej znacząca różnica w odpowiedziach w obu porównywanych środowiskach, która wpłynęła na ogólną niższą samoocenę badanego zjawiska polskich studentów w porównaniu do niemieckich.

Dodatkowo polscy studenci nisko ocenili liczbę ofert pracy w regionie, w którym chcieliby pracować, i to wszystkich ofert, nie tylko związanych z zawodami informacyjnymi.

Natomiast mając na uwadze podobieństwa badanych grup zauważono, że ponad połowa respondentów w obu środowiskach nie znała (wybór odpowiedzi nie wiem) opinii pracodawców o uczelni, na której studiują, tzn. nie wiedziała czy pracodawcy chętnie zatrudniają absolwentów danego uniwersytetu, zarówno pracodawcy związani z działalnością informacyjną, jak i z innych obszarów.

Przeprowadzona analiza porównawcza, jako pierwsza tego rodzaju w zakresie badań nad zatrudnialnością studentów z pewnością nie wyczerpuje tematu, jest tylko przyczynkiem do dalszych analiz, stworzyła jednak zarys problemu, warty dalszej dyskusji w ośrodkach kształcenia infobrokerów, architektów informacji i bibliotekarzy.

\section{Bibliografia}

Rothwell, A.; Hervert, I.; Rothwell, F. (2008). Self-Perceived Employability: Construction and Initial Validation of a Scale for University Students. Journal of Vocational Behavior, 73, 1-12.

Rothwell, A.; Jewell, S.; Hardie, M. (2009). Self-perceived Employability: Investigating the Responses of Post-Graduate Students. Journal of Vocational Behavior, 75, 152-161.

Świgoń, M. (2014a). Potencjał kariery studentów kierunków i specjalności informatologicznych. Teraźniejszość - Człowiek - Edukacja, 66(2), 79-90.

Świgoń, M. (2014b). Samoocena potencjału zawodowego studentów informacji naukowej i bibliotekoznawstwa oraz specjalności info- i bibliologicznych. Wyniki badań z przełomu 2010 i 2011 roku. Zagadnienia Informacji Naukowej, 52(2), 135-148.

Świgoń, M. (2013). Personal Knowledge and Information Management - Conception and Exemplification. Journal of Information Science, 39(6), 832-845. 


\title{
The Comparison of Self-Perceived Employability of German and Polish Students of Library and Information Science Majors and Specializations
}

\begin{abstract}
Purpose/Thesis: The aim of the study was a comparison of self-perceived employability of German and Polish students of Library and Information Science majors and specializations.

Approach/Methods: The same questionnaire was used in both environments, compatible with the model of students' employability. This model includes, among others, the involvement in the studies and academic performance, the perception of the strength of the university brand, the reputation the university has within the field of study, the status of the field of study, the demand of the labor market for the professionals of the subject field, the perception of the current state of the labor market, the awareness of opportunities in the labor market, the confidence in skills and competences; and last, but not the least - personal knowledge and information management.

Results and conclusions: The level of self-assessment of Polish respondents' employability was lower than that of German respondents, particularly as regards the scope of the status of the study field and the demand of the labor market for the professionals of the subject field.

Originality/Value: The study was the first attempt of the comparison of German and Polish students' employability.
\end{abstract}

Keywords

Employability. Library and Information Science schools. Personal knowledge and information management. Students.

Dr hab. MARZENA ŚWIGOŃ, prof. UWM specjalizuje się w problematyce zarzadzania i dzielenia się informacja $i$ wiedza. Habilitowała się w zakresie bibliologii i informatologii na Uniwersytecie Wroctawskim w 2013 r. Pracuje w Instytucie Historii i Stosunków Międzynarodowych Uniwersytetu Warmińsko-Mazurskiego w Olsztynie. Najważniejsze publikacje: Personal Knowledge and Information Management - conception and exemplification. Journal of Information Science 2013, 39(6); Library anxiety among Polish students: development and validation of the Polish Library Anxiety Scale. Library \& Information Science Research 2011, 33(2); Information limits - definition, types and typologies. Aslib Proceedings: new information perspectives 2011, 63(4).

\author{
Kontakt $z$ autorem: \\ marzena.swigon@uwm.edu.pl \\ Instytut Historii i Stosunków Międzynarodowych \\ Zaktad Archiwistyki, Bibliotekoznawstwa i Informacji Naukowej \\ Uniwersytet Warmińsko-Mazurski w Olsztynie \\ ul. Kurta Obitza 1 \\ 10-725 Olsztyn
}

